\title{
Effectiveness of Whey Protein Supplement in Resistance Trained Individuals
}

\section{Fernando Naclerio ${ }^{1,3 *}$ Ahmad Alkhatib ${ }^{1}$ and Alfonso Jimenez ${ }^{2}$}

${ }^{1}$ Centre of Sport Science and Human Performance, School of Science, University of Greenwich, UK

${ }^{2}$ School of Sports Science, European University of Madrid, Spain

${ }^{3}$ Institute of Sport, Exercise and Active Living (ISEAL), Victoria University, Melbourne, Australia

\begin{abstract}
Athletes and recreationally resistance-trained individuals often use protein supplements in an attempt to maximize their training gains and performance. Because of the high bioavailability and solubility and its higher proportion of essential amino acids including Leucine, whey protein extract has been proposed as the best optimal form of protein for strength and power athletes. The objective of this review is to examine the current evidence for the efficacy of whey protein containing supplements to optimize strength training adaptation and outcomes for regular resistance training practitioners.
\end{abstract}

A limited numbers of studies have reported positive effects of whey protein containing supplements (including those with carbohydrate and creatine) for optimizing the anabolic responses and adaptations process in resistancetrained individuals.

In order to promote a more anabolic environment and maximize muscle protein synthesis along the day, an eating pattern behavior involving frequents meals (every 3 to $5 \mathrm{~h}$ ) containing 17 to $20 \mathrm{~g}$ of high quality protein ( 200 to $250 \mathrm{mg} /$ $\mathrm{kg}$ ) providing 8 to $10 \mathrm{~g}$ of EAA (90 to $110 \mathrm{mg} / \mathrm{kg}$ ) and about $2 \mathrm{~g}$ of Leucine (20 to $25 \mathrm{mg} / \mathrm{kg}$ ) have been recommended. Special attention should be given to the periworkout hours where the ingestion of whey proteins combined with carbohydrates, creatine monohydrate $(0.1 \mathrm{~g} / \mathrm{kg} / \mathrm{d})$ and other proteins sources such as casein before, during and after workout have been shown to improve training adaptations and enhance the recovery process. However, when considering that the training conditions (workout volume, organization, number of exercises) used in the available studies are substantially different than what athletes actually perform. Optimal whey protein supplementation protocols need to specifically be based on the regular resistance training workout organization and would probably need to consider other doses and timing strategies than what is currently recommended.

Keywords: Multinutrient; Supplementation; Strength and power athletes; Amino acid; Leucine; casein; Sport-nutrition

Abbreviations: LBM: Lean Body Mass; AA: Amino Acid; PDCAAS: Protein Digestibility Corrected Amino Acid Score; DIAAS: Digestible Indispensable Amino Acid Score; EAA: Essential Amino Acid; BCAA: Branched Chain Amino Acid

\section{Introduction}

The protein requirements for athletic populations have been the subject of extensive scientific debate. During the last decade the notion that athletes as well generally active population require greater protein intake than the currently RDA recommendation of $0.8 \mathrm{~g} / \mathrm{kg}$ of body weight per day in healthy adults has become well accepted $[1,2]$. In addition, high protein diets have also become quite popular in general population as part of many weight reduction programs $[3,4]$. Differences in protein requirements for different types of athletes (i.e., endurance, strength/power) and non-athletes are well documented [58]. Many studies have investigated the effects of protein obtained from different sources such as milk eggs soy rice or bovine colostrum as well as the technique used to manufacture the protein supplements or the methodology recommended for their ingestion [9-15]. In fact, these factors can be very relevant when the protein supplements are ingested with the scope to optimize training adaptations [16].

Although some studies have shown greater strength, muscular hypertrophy and/or Lean Body Mass (LBM) gains when resistance training is combined with whey protein alone or in conjunction with carbohydrates other protein sources enriched with amino acids or creatine; there are still some inconsistencies regarding the most appropriate effective doses and ingestion-timing strategy for optimizing resistance training induced adaptations and outcomes (strength gain or muscle mass accretion) [17-21].
As the focus of this review is on the effects of whey protein supplementation on both resistance training performances and their outcomes in trained individuals, we have focused on reviewing the evidence that have used whey protein preparation alone or combined with other protein sources or amino acid derivatives for optimizing resistance training responses for regular athletes and recreationally resistance training individuals. Thus, after describing the main characteristics of whey protein supplements, manufacture process, quality and Amino Acid (AA) profile; we will analyze the documented effects of whey protein containing supplements for resistance-trained individuals. In addition some practical recommendations about the most appropriate serving sizes and feeding distribution strategies will be provided based on current level of evidences.

\section{Protein Supplements}

Most of protein extract are obtained from milk, eggs, bovine colostrums, soy and to less extend from bean, wheat or rice. The quality of these extracts may vary depending on the type and quality

*Corresponding author: Fernando Naclerio, Centre of Sport Science and Human Performance, School of Science, University of Greenwich, Medway Campus Central Avenue, Chatham Maritime, Kent ME4 4TB, UK, Tel: +44 (0)20 8331 8441; Fax: +44 (0) 208331 9805; E-mail: f.j.naclerio@gre.ac.uk

Received August 30, 2013; Accepted October 03, 2013; Published October 10 2013

Citation: Naclerio F, Alkhatib A, Jimenez A (2013) Effectiveness of Whey Protein Supplement in Resistance Trained Individuals. J Sports Med Doping Stud 3: 130 doi:10.4172/2161-0673.1000130

Copyright: (c) 2013 Naclerio F, et al. This is an open-access article distributed under the terms of the Creative Commons Attribution License, which permits unrestricted use, distribution, and reproduction in any medium, provided the original author and source are credited. 
of the manufacturing process. A range of processed milk proteins (concentrates, isolates, hydrolyzate or peptides) has been used for different purposes including change in metabolic health in young or elderly people or training optimization outcomes in untrained recreationally active or well trained athletes [19,22-26].

\section{Milk composition: Protein sub-fractions manufacturing and main differences}

Whole milk is approximately $87 \%$ water, with the remaining $13 \%$ as solids. The $13 \%$ solids are composed of $30 \%$ fat, $37 \%$ lactose, $27 \%$ protein, and $6 \%$ minerals. Of the $27 \%$ of milk that is protein, $20 \%$ is whey protein and $80 \%$ is casein protein [27]. During the process of making cheese, whey protein is separated out into a transparent liquid fraction that has shown to be a good source of high quality protein currently used to produce protein powders and many other products.

Milk protein concentrate, produced by ultrafiltration of skimmed milk, contains both casein and whey proteins in similar proportions to whole milk, but the total amount of protein, lactose and mineral content may vary between different formulations [14].

The casein fraction comprises $\alpha$-casein, $\beta$-casein, and $\kappa$-casein whilst whey contain multiple globular proteins including $\beta$-lactoglobulin $(50$ to $55 \%$ ), $\alpha$-lactalbumin (20 to $25 \%$ ) bovine serum albumin (5 to $10 \%$ ) lactoferrin (1 to $2 \%$ ) immunoglobulins (10 to $15 \%$ ) lactoperoxidase enzymes $(\sim 0.5 \%)$ and glycomacropeptides (10 to $15 \%)$, enzymes and growth factors. All of these components have been associated with the potential to improve general health outcomes and disease prevention reduce immunosuppression attenuate muscular inflammatory related damage optimize recovery process and resistance training outcomes in athletes and enhance metabolic health in general population [19-22,2830].

Whey fraction of the milk is particularly rich in essential amino acid, vitamins and mineral [14]. Protein concentrates obtained from whey are produced by coagulation of milk with the enzyme rennet or acid, resulting in separation of curds and whey, further ultrafiltration and drying produces whey protein concentrates containing $\approx 25-80 \%$ protein [31]. Additional processing can produce whey protein isolates containing $>90 \%$ protein with very low amounts of lactose and lipids [28]. Selective elution, also known as ion exchange chromatography, is the process most often used to produce whey protein isolates [14]. Additional hydrolysis with enzymes or acids provides a way to breakdown the structure of protein containing in whey [22]. As the acids hydrolysis process would also lower the quality and biological value of protein, the addition of proteolytic enzymes, followed by purification procedures is greatly preferred [32]. The main advantage of high quality whey protein ion exchanges hydrolyzates preparations would be the rapid uptake and availability of AA and a possible strong insulinotropic effect that would elicited a fast and powerful stimulus on muscle protein synthesis during the $3 \mathrm{~h}$ postprandial period $[33,34]$. This advantageous postprandial effect of whey protein contributes to numerous anabolic responses following resistance training and its supplementation has been recently shown to have superior cardio-protective effects on postprandial lipemia compared with other common dietary protein supplementations such as cod or gluten $[25,35]$.

With high quality of manufacturing the native structures of whey protein can be retained. However, some minor peptides such as lactoferrin may have a decreased concentration, while the $\beta$-lactoglobulin protein fraction tends to increase in whey protein isolates [27]. Thus, protein isolates tend to be low in glycomacropeptides, lactoferrin, lactoperoxidase and some bioactive peptides. However, a high quality process of microfiltration/ultrafiltration would produce whey protein isolates with higher amounts of glycomacropeptides, lactoferrin, lactoperoxidase and the bioactive peptides, and lower in bovine serum albumin. Cross-flow microfiltration gives a whey protein isolate which is greater than $90 \%$ in protein that is under-natured and that retains all important sub-fractions in natural ratios, with no fat or lactose [14].

There is indication that lactoferrin and some of the immunoglobulins in whey proteins may be more resistant to proteolytic degradation than are other types of proteins. Some proteins e.g. bovine serum albumin or beta-lactoglobulin may yield glutamylcysteine during their digestion, which may be absorbed and serve as a precursor to glutathione (potent antioxidant precursor) in some tissues [36].

In summary, when whey proteins preparation are processed with high quality process using low temperatures and not exposed to fluctuating $\mathrm{pH}$ changes the undesirable denaturing of native structures would be avoided.

Casein is the protein source of cheese and forms curds during processing because it exists as a micelle in milk [27]. As nutritional supplements casein is made of to rennet casein or caseinates; which is an acid form usually combined with sodium, calcium, or potassium. The low $\mathrm{pH}$ conditions in the stomach cause casein to clot, forms clumps or curds and delay gastric emptying [37]. Different from whey protein that remain soluble in the stomach, and thus are emptied rapidly, casein is converted into a solid clot, and emptied more slowly from the stomach [38]. These differences in digestive properties are likely to contribute to the different patterns of AA concentrations that have been observed after ingestion of whey or casein protein $[24,38]$. Therefore, casein has been termed as "slow", and whey has been termed as "fast" protein $[39,40]$.

In general, the slowly absorbed casein protein would promote a more sustained and prolonged postprandial protein deposition by an inhibition of protein breakdown without excessive increase in amino acid concentration. By contrast, a fast whey protein stimulates protein synthesis but also oxidation. This impact of amino acid absorption speed on protein metabolism is true when proteins are given alone, this might be blunted in more complex meals that could affect gastric emptying (lipids) and or insulin response (carbohydrates) [41]. Additionally the more prolonged anabolic effects of casein seems to be effective in resting condition while after training the ingestion of one single dose of whey protein has been proposed as to be more effective to stimulate anabolic responses in resistance trained individuals $[5,25]$.

\section{Amino acid profile of whey and casein protein supplements}

Based on human AA requirements, digestibility and their bioavailability, similar to eggs protein, both whey and casein protein have been classified as high quality proteins [31]. Considering both the protein digestibility corrected AA score (PDCAAS) and the recently developed digestible indispensable AA score (DIAAS), casein and whey protein fractions contain higher amount and proportion of essential amino acids (EAA) compared to other vegetable protein sources such as soy or rice [42]. Nevertheless, in addition to their different digestive patters, some special physiological effects have also been attributed to their particular AA composition [43]. Figure 1 compares the AA compositions of the whey and casein protein fractions [24].

Data from Figure 1 indicates that when the same amount of casein or whey protein are consumed, whey provide more than $3 \%$ of EAA and higher amount of Cysteine, and Leucine. Cysteine is thought to play a key role in the regulation of whole body protein metabolism, 


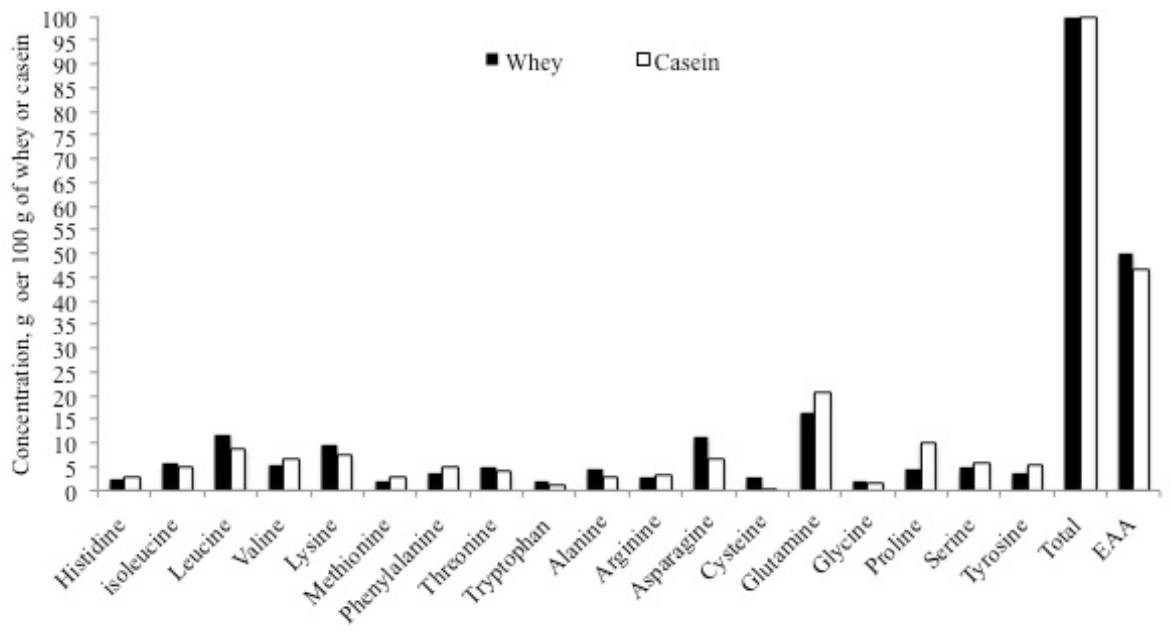

Figure 1: Comparison between whey and casein amino acid profile.

acting as a potent anticatabolic and antioxidant agent [45]. Cysteine supplementation has been shown to promotes glutathione synthesis, and shifts whole body nitrogen disposal in favor of preserving the muscle amino acid pool [45].

Leucine, one of the Branched Chain Amino acid (BCAA) is a key essential AA to trigger a potent increase in protein synthesis when a minimum amount of $1 \mathrm{~g}$ or $2 \mathrm{~g}$ per meal is consumed by young or elderly people respectively [46].

On the other side, whey protein contains lower quantities of Methionine, Glutamine, Arginine and Tyrosine. Additionally both whey and casein contain lower or trace amount of Taurine, which is a conditionally essential amino acid, involved in a number of physiological processes including cell membrane stabilization, neural excitability or sensibility for nutrient intake into the cell. Even when is the most abundant free amino acid in excitable tissue such as muscle heart and brain it is not used to build protein but has important functions as insulin mimetic, cellular hydration and protein synthesis stimulation [47].

As the above mentioned amino acids have important neuronal and metabolic functions, in order to maximize the nutritional proprieties of the whey protein extract, a high quality based whey protein product could be fortified with the addition of peptides of L-Glutamine, L-Arginine, L-Taurine, L-Methionine and L-Tyrosine [14,31]. For example, glutamine accounts for $30-35 \%$ of the amino acid nitrogen in the plasma being the most abundant amino acid in blood. L-glutamine fulfills a number of biochemical needs. It operates as a nitrogen shuttle, taking up excess ammonia and forming urea. It can act as a powerful anticatabolic agent contributing for the production of other AAs, glucose, nucleotides, protein, and glutathione [42]. Arginine is a semi-essential $\mathrm{AA}$, involved in numerous areas of human biochemistry, including ammonia detoxification, hormone secretion, and immune modulation. L-arginine is the main physiological precursor of nitric oxide that plays an important regulatory role by increasing blood flow to the muscles and modulating muscle contraction, glucose and AAs uptake by the muscle [30]. Methionine is an essential AA associated with the methyl donor reactions for the synthesis of epinephrine, creatine, melatonin, glutathione, the polyamines spermine and spermidine, as well as the AAs L-cysteine and taurine, all of which play vital roles in human health [48]. Tyrosine in addition to support phenylalanine levels, is essential for the production of catecholamine neurotransmitters, including dopamine, norepinephrine, and epinephrine. Tyrosine is the precursor for the hormones thyroxine and triiodothyronine by the thyroid gland and grow hormone by the pituitary [49]. There is some evidence that supplementation with L-tyrosine can lead to an increase in dopamine that in turn may lead to an improvement in mood state [50].

Although, each protein source has unique attributes that may convey specific nutritional advantages compared to the others (general health benefits, body weight management, gaining lean body mass, enhancing muscle recovery after exercise or stimulating muscular protein synthesis) the degree by which each source of protein can stimulate these process are related to different factors involving digestion rates, divergent AA profiles, pattern of ingestion and the metabolic state (rest or exercise) related to the timing of ingestion $[39,40]$.

\section{Documented Effects of Whey Protein Supplement to Optimize Resistance-Training Responses}

Whey protein extract, because of its increased bioavailability and solubility, and its higher percentage content of EAA including BCAAs, specifically Leucine, has been proposed as the best optimal form of protein for strength and power athletes [17,45,51]. Although several studies have analysed the effect of whey protein supplementation on resistance training performance and outcomes only some of them have focused on resistance trained individuals $[12,17,23,24,26,38,52,53]$.

Cribb et al., [45] reported higher significant improvements in LBM, strength and loss of body fat in a group of recreational bodybuilders who supplemented their diet with the addition of $1.5 \mathrm{~g} / \mathrm{kg} / \mathrm{d}$ of hydrolyzed whey protein isolate compared to other group who ingested the same amount of casein during a supervised 10-week resistance training program. The $1.5 \mathrm{~g} / \mathrm{kg} / \mathrm{d}$ supplement dose was divided into smaller equal servings and consumed throughout the day (e.g. breakfast, lunch, immediately after training, and dinner).

Kraemer et al., [53], analysed the effects of 14 days supplementation period in 10 resistance trained males who were exposed to three different supplementation protocols: $20 \mathrm{~g}$ of whey protein isolate, $20 \mathrm{~g}$ of soy protein isolate or $20 \mathrm{~g}$ of carbohydrates. Each participant completed all three conditions separated by a two weeks wash out period. Lower cortisol and higher total testosterone levels were measured from 5 to 30 min after performing a squat protocol involving 6 sets of 10 
repetitions at $80 \% 1 \mathrm{RM}$ followed by the whey protein supplementation period compared to when participants were exposed to soy or placebo. In addition, whey supplementation might also attenuate the normal increase of cortisol observed after carbohydrate condition.

Tang et al. [17] reported positive effects of $10 \mathrm{~g}$ of whey protein combined with $21 \mathrm{~g}$ of fructose, to induce a 2 -fold rise in muscle protein synthesis in young well resistance trained men, over $4 \mathrm{~h}$, after performing 4 sets of $8-10$ repetitions at $80 \% 1 \mathrm{RM}$ for the leg press and leg extension exercises.

As whey protein contains about $50 \%$ of EAA, $10 \mathrm{~g}$ of whey high quality extract would provide circa $5 \mathrm{~g}$ of EAA [24]. If we consider that $20 \mathrm{~g}$ of whole egg protein, containing $8.6 \mathrm{~g}$ of EAA including 2 $\mathrm{g}$ or Leucine, have been necessary to maximally stimulate muscle and albumin protein synthesis after a lower-body resistance exercise in young men it may be possible that even when $10 \mathrm{~g}$ of whey protein were sufficient to elicit significant increases of muscle protein synthesis, a higher dose $(\approx 17 \mathrm{~g})$ would be necessary to achieve the optimal maximal response beyond which a marked stimulation of whole-body AA oxidation with no further increase in muscle protein synthesis would occur in young resistance trained males [10].

High-quality proteins extract, such as whey, stimulate muscle protein synthesis in proportion to the amount of EAA and specifically Leucine administered per serving [38]. Norton and Wilson suggest that optimal protein intake per meal should be based on the amount of leucine provided by the source of protein consumed [54]. Thus, the presence of the relative amount of the EAA including Leucine is of cornerstone importance for determining the amount of protein to be ingested in every meal. In fact when the amount of EAA and Leucine are equated the effects on muscle protein synthesis and training outcomes seems to be similar regardless of which protein source is consumed [12,54]. Joy et al. [12], observed no differences of ingesting either $48 \mathrm{~g}$ of isolate protein extracted from rice or whey during 8 weeks of daily ondulated periodized resistance training program on short term recovery (Ratings of perceived recovery, soreness, and readiness) or training-induced adaptations (increase lean body mass, muscle mass, strength and power and decrease fat mass) in 24 resistance trained young males. Even when the absence of control group did not allow the authors to conclude how beneficial whey or rise proteins supplementation would be compared to resistance training alone, based on previous investigations it could be possible to say that regardless of the source, between 17 to $20 \mathrm{~g}$ of high quality protein $(200$ to $250 \mathrm{mg} / \mathrm{kg}$ ) providing 8 to $10 \mathrm{~g}$ of EAA (90 to $110 \mathrm{mg} / \mathrm{kg}$ ) and about $2 \mathrm{~g}$ of Leucine ( 20 to $25 \mathrm{mg} / \mathrm{kg}$ ) would be necessary to elicit an optimal muscle protein synthesis response in young strength trained individuals after performing a typical resistance training workout $[10,17]$. As a consequence, when ingested others plant-based protein extracts such as soy or rice containing less proportion of EAA and leucine, in order to obtain similar results, higher doses should be administered. However, larger protein ingestion entail also higher caloric intake greater digestion time (slower release of AA to the periphery), and increased AA oxidation and ureagenesis because more proportion of AA would be converted to urea rather than used for protein synthesis [5].

Summarizing the previous information, even when the need of EAA and Leucine could be satisfied from different protein sources, whey protein extract seems to be more efficient, on a gram per gram basis.

\section{Whey protein combined with carbohydrates, other proteins sources, amino acid and/or creatine}

Added carbohydrates to whey protein extract have been shown to enhance cellular hydration, glycogen resynthesis and reduce muscle protein breakdown which then magnifies the increase in net protein balance and/or lessen the immunosuppressive effects of exercise compared to the ingestion of whey protein or AA alone $[8,55,56]$. These positive effects are in part related to a more powerful insulin secretion [54]. With regard to resistance training, the ingestion of $40 \mathrm{~g}$ of whey protein with 120 of sucrose, honey powder or maltodextrine (1:3 protein to carbohydrate ratio) following a typical resistance training workout involving 9 exercises of 3 sets per 10 rep at $70 \% 1 \mathrm{RM}$, did significantly influence glucose and insulin responses without significantly altering markers of anabolism, catabolism or immunity during the first two hours of recovery [18].

Multinutrients supplements containing whey protein, carbohydrates, amino acids, and other natural compounds such a creatine may optimize recovery time and training induced adaptation [19-21,57-59].

Kerksick et al. [20] reported significant greater increases in fat free mass in 36 resistance-trained men after combining a 10 weeks strength training program with the ingestion of $40 \mathrm{~g}$ whey plus $8 \mathrm{~g}$ casein and $2 \mathrm{~g}$ of carbohydrates compared to both a carbohydrate-placebo and a similar multinutrient containing only $40 \mathrm{~g}$ of whey enriched with $3 \mathrm{~g}$ of BCAAs, 5 of glutamine and $2 \mathrm{~g}$ of carbohydrates. Supplements where ingested within 2 hours after workout during training days or at the morning on non-training days. Authors concluded that co-ingestion of blend high quality whey and casein proteins mix may be an effective means to promote higher improvements on body composition in resistance-trained individuals compared to the ingestion of only one protein source.

As stated previously whey and casein possess different patterns of amino acid release, which has been shown to greatly affect the extracellular amino acid concentrations and the resulting levels of protein synthesis and breakdown [60]. Differences in digestion rates would cause a more sustained increase in blood amino acid levels, resulting in greater muscle amino acid uptake [39]. Casein tends to inhibit protein catabolism when consumed at rest and has a slight, but relatively long increase in protein synthesis. The pattern of amino acid delivery with casein appears to lead to better leucine balance (net protein state) than whey at rest [5]. Conversely, after a typical resistance training workout whey protein have shown to stimulates a greater acute (0-3 $\mathrm{h}$ post-exercise) rise in muscle protein synthesis compared with the same amount of casein and is still highly effective for stimulating muscle protein synthesis over $3-5 \mathrm{~h}$ post-exercise [60-62]. Thus, possibly when both types of proteins sources are combined, in addition to a more favorable AA muscle blood-flow after workout, a higher aminoacidemia would be sustained along the day. As the stimulation of protein synthesis may be largely depend on the availability of the extracellular concentration of AA, for resistance trained practitioners, the co-ingestion of fast (whey) and slow (casein) high quality protein extract would elicit a more powerful anabolic and effective stimulus compared to only one source.

Cribb et al. [21] examined the effects of 11 weeks of resistance training program combined with whey protein and/or creatine monohydrate (both separately and in combination) on body composition, muscle strength, and muscular hypertrophy in a group of recreational male bodybuilders. Participants were dived in 4 groups: whey protein; whey protein plus creatine monohydrate; carbohydrates and carbohydrates plus creatine monohydrate. Supplementation with whey protein, whey protein plus creatine monohydrates and carbohydrates plus creatine monohydrate resulted in greater hypertrophy responses and strength 
gains compared to the ingestion of only carbohydrates. Additionally, the consumption of a creatine monohydrate in conjunction with whey proteins or carbohydrates provides similar benefits that in addition were greater than those obtained from carbohydrates or whey protein alone. In the line with the previous investigation, Cooper et al. [59] reported greater possibilities for improving $1 \mathrm{RM}$ bench press (78\%) and upper and lower body muscular endurance (49\%) when a group of resistance trained males who performed a 12 weeks resistance-training program ingested 2 serving of $60 \mathrm{~g}$ per day of a multinutrient containing $21 \mathrm{~g}$ of carbohydrate, $30 \mathrm{~g}$ of whey protein, $4.7 \mathrm{~g}$ of fat, $5.1 \mathrm{~g}$ of creatine, $5.1 \mathrm{~g}$ of glutamine and $1.5 \mathrm{~g}$ HMB instead of a carbohydrate-placebo.

Summarizing the previous information, in addition to the synergic effects of adding carbohydrates, in order to optimize the positive effects of whey protein for improving resistance training adaptation, combining other protein sources such as casein and specifically the addition of creatine monohydrate would be appropriate. On the other hand, the additional benefits on resistance training outcomes resulted from the addition of other AA or proteins derivatives such as glutamine, BCAAs or HMB remain to be elucidated.

\section{Whey protein supplementation protocol: the nutrient-timing strategy}

Unfortunately there is no conclusive evidence about what time point and dose are optimal for the ingestion of protein or amino acid-carbohydrate supplement for optimizing muscular adaptations to exercise. Many studies have provided positive results for ingesting high quality protein before, during, immediately after or several hours ( 1 to $3-5 \mathrm{~h}$ ) post exercise for promoting increases in protein synthesis [58]. With regard to the most convenient nutrition-timeprotocol for improving resistance training outcomes, Cribb and Hayes reported significantly greater increases in lean body mass, strength and hypertrophy after 10 weeks of resistance training in a group of trained males who ingested a multinutrient contained glucose, whey isolate, creatine monohydrate and fat just before and after workout compared to another group which consumed the same dose before breakfast and just prior retiring to bed [26].

The optimal feeding strategy to maximally enhance recovery and anabolic response to resistance exercises should also consider the serving size and feeding distribution before, during and after workout. West et al., [25] observed greater muscular protein synthesis for $5 \mathrm{~h}$ of recovery in 8 recreationally trained males when consuming a 25 g single-bolus-dose of whey protein after performing 8 sets of $8-10$ repetitions of a bilateral leg extension compared to the same amount of proteins ingested as repeated, small pulsed drinks (10 doses of 2.5 $\mathrm{g}$ of whey protein every $20 \mathrm{~min}$ ). In another similar study, Burke et al. [63] observed different patterns of aminoacidemia in 12 resistance trained males who ingested $25 \mathrm{~g}$ of whey protein enriched with $5 \mathrm{~g}$ of Leucine or placebo before performing 1 set $\times 8-10$ repetition at $80 \%$
$1 \mathrm{RM}$ in a single leg extension exercise. Supplements were administered in a single-bolus-dose ( $45 \mathrm{~min}$ before) or as a series of 15 small-pulsed drinks, (of approximately $33 \mathrm{~mL}$ each) starting $45 \mathrm{~min}$ before and ended $2 \mathrm{~h}$ after completed the training. Although similar increases in muscle protein synthesis (near $250 \%$ respect to placebo) were observed over $5 \mathrm{~h}$ after exercise, in the early phase of recovery the pulsed strategy produced higher AA and insulin concentration.

If we assume that between 17 to $20 \mathrm{~g}$ of high quality protein providing 8 to $10 \mathrm{~g}$ of EAA are necessary to maximally stimulates muscle protein synthesis after exercises, considering that a typical resistance training workout enhance muscle protein synthesis for at least $24 \mathrm{~h}$; in order to maximize the anabolic effects of feeding it should be necessary to maintain a frequent protein ingestion, not only during the periworkout period but also along the day $[64,65]$. Because muscle protein synthesis becomes refractory to persistent aminoacidemia in order to maintain an optimal protein synthesis stimulation, between 5 to 6 meals providing 17 to $20 \mathrm{~g}$ of high quality protein should be recommended [54]. In line with this rationale, Areta et al., [66] examined the effects of three different protein feeding distributions over a $12 \mathrm{~h}$ recovery period in 24 resistance trained male who performed 4 sets of 10 repetitions at $80 \% 1 \mathrm{RM}$ with $3 \mathrm{~min}$ rest between sets followed by the ingestion of $80 \mathrm{~g}$ of whey protein isolate. Participants were divided in three groups: Pulse (ingested 8 servings of $10 \mathrm{~g}$ every $1.5 \mathrm{~h}$ ); Intermediate (ingested 4 servings of $20 \mathrm{~g}$ every $4 \mathrm{~h}$ ) and bolus (ingested 2 servings of $40 \mathrm{~g}$ every $6 \mathrm{~h})$. Results showed higher myofibrillar protein synthesis stimulation for the intermediate protocol ( 4 intakes of $20 \mathrm{~g}$ ) compared to both pulse ( 8 servings of $10 \mathrm{~g}$ ) and bolus ( 2 servings of $40 \mathrm{~g}$ ). Possibly $10 \mathrm{~g}$ of whey protein is not enough and resulted in some suboptimal stimulation of the protein synthesis. In contrast, larger but less frequent servings of 40 $\mathrm{g}$, even if should be appropriate to maximally stimulate muscle protein synthesis, represent a suboptimal ingestion pattern due to irreversible amino acid oxidation of the excess ingested protein and possible the lack of anabolic stimulus between intakes $(>5 \mathrm{~h})$.

In summary as the cell membrane is highly sensitive to the internal and external (blood) rise of AA concentration, frequent meals (every 3 to $5 \mathrm{~h}$ ) containing 17 to $20 \mathrm{~g}$ or high quality protein would potentiate and maintain a long lasting and optimal muscular protein synthesis stimulus. Additionally, with the aim to maximize the anabolic response of resistance training workout a higher protein intake (bolus) should be provided immediately after training. Figure 2 depicts the theoretical optimal protein-feeding pattern protocol starting $3 \mathrm{~h}$ before (small intakes $\approx 10 \mathrm{~g}$ ) and ending $6 \mathrm{~h}$ after training (higher intakes $\approx 20 \mathrm{~g}$ ).

It is important to note that even when high quality whey protein extract would be an appropriate option for ingesting during training and just after workout others protein sources including those coming from regular food such as eggs, meet, cheese etc can be used along the different daily meals [67].

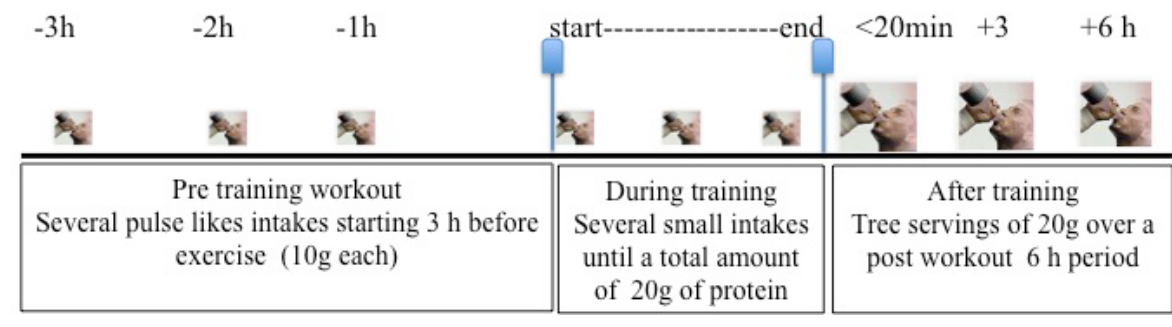

Figure 2: Proposed ideal protocol of protein feeding for the periworkout hours. 


\section{Contraindications and Precautions Related to Whey Protein Extract Ingestion}

To date, no severe adverse reactions have been reported following administration of whey protein extracts. Although some individuals, who are hypersensitive to milk proteins, can experience allergy symptoms including possible serious ones (in this case is strongly recommended to avoid whey proteins containing products). Other dairy-sensitive individuals are lactose-intolerant. Most whey proteins are processed to remove lactose and finished whey products only contain trace amounts. De-lactosed whey, produced from crystallizing a majority of the lactose out and recovering the remaining whey, is appropriate for lactose-intolerant individuals [28].

\section{Conclusions and Final Recommendations}

The optimal protocol for administering a supplement containing high quality whey protein still needs to be determined. However in order to stimulate a more powerful anabolic response, frequent meals (every 3 to $5 \mathrm{~h}$ ) containing 17 to $20 \mathrm{~g}$ of high quality protein (200 to $250 \mathrm{mg} / \mathrm{kg}$ ) providing 8 to $10 \mathrm{~g}$ of EAA (90 to $110 \mathrm{mg} / \mathrm{kg}$ ) and about 2 g of Leucine (20 to $25 \mathrm{mg} / \mathrm{kg}$ ) seems appropriate for eliciting optimal muscular responses and adaptations in resistance training practitioners.

Co-ingestion of whey protein and carbohydrates in 1:3 ratio would helps glycogen restoration and inhibits protein catabolism, creating synergistic effects with the EAA, particularly leucine, for optimizing recovery process after resistance training workout [68].

Special attention should be given to the periworkout hours where the ingestion of small amount of whey protein $(\approx 10 \mathrm{~g})$ under a pulse like protocol should began $3 \mathrm{~h}$ before and continue through the training session. A higher protein intake $(\approx 20 \mathrm{~g})$ would be recommended immediately post workout and possibly at 3 and $6 \mathrm{~h}$ after training. In addition, combined whey with others protein sources such as casein and specifically with creatine monohydrate $(0.1 \mathrm{~g} / \mathrm{kg} / \mathrm{d})$, would be appropriate for improving recovery process and the anabolic responses induced by resistance training in athletes [69].

Most available studies have analysed the results based on serial biopsies of only one muscle and limited training conditions (low volume and number of exercises) that are substantially different from what athletes actually perform.

Future research may explore the responses of regular resistance training practitioners under most realistic training condition, using others timing strategies and possibly higher proteins doses than what is currently being recommended.

\section{References}

1. American Dietetic Association; Dietitians of Canada; American College of Sports Medicine, Rodriguez NR, Di Marco NM, Langley S (2009) American College of Sports Medicine position stand. Nutrition and athletic performance. Med Sci Sports Exerc 41: 709-731.

2. Campbell B, Kreider RB (2008) Conjugated linoleic acids. Curr Sports Med Rep 7: 237-241.

3. Layman DK, Shiue H, Sather C, Erickson DJ, Baum J (2003) Increased dietary protein modifies glucose and insulin homeostasis in adult women during weight loss. J Nutr 133: 405-410.

4. Volek JS, Forsythe C (2008) Very-Low Carbohydrate Diets, Chapter 25, in Essential of Sports Nutrition and supplements, J Antonio, Kalman D, Stout JR, Greenwood M, Willoughby DS, et al. (Eds.), Humana Press. 581-603.

5. Bilsborough S, Mann N (2006) A review of issues of dietary protein intake in humans. Int J Sport Nutr Exerc Metab 16: 129-152.

6. Paddon-Jones D, Sheffield-Moore M, Zhang XJ, Volpi E, Wolf SE, et al. (2004)
Amino acid ingestion improves muscle protein synthesis in the young and elderly. Am J Physiol Endocrinol Metab 286: E321-328.

7. Børsheim E, Tipton KD, Wolf SE, Wolfe RR (2002) Essential amino acids and muscle protein recovery from resistance exercise. Am J Physiol Endocrinol Metab 283: E648-657.

8. Tipton KD, Wolfe RR (2001) Exercise, protein metabolism, and muscle growth Int J Sport Nutr Exerc Metab 11: 109-132.

9. Elliot TA, Cree MG, Sanford AP, Wolfe RR, Tipton KD (2006) Milk ingestion stimulates net muscle protein synthesis following resistance exercise. Med Sci Sports Exerc 38: 667-674.

10. Moore DR, Robinson MJ, Fry JL, Tang JE, Glover El, et al. (2009) Ingested protein dose response of muscle and albumin protein synthesis after resistance exercise in young men. Am J Clin Nutr 89: 161-168.

11. Zhan S, Ho SC (2005) Meta-analysis of the effects of soy protein containing isoflavones on the lipid profile. Am J Clin Nutr 81: 397-408.

12. Joy JM, Lowery RP, Wilson JM, Purpura M, De Souza EO, et al. (2013) The effects of 8 weeks of whey or rice protein supplementation on body composition and exercise performance. Nutr J 12: 86.

13. Shing CM, Hunter DC, Stevenson LM (2009) Bovine colostrum supplementation and exercise performance: potential mechanisms. Sports Med 39: 1033-1054.

14. Etzel MR (2004) Manufacture and use of dairy protein fractions. J Nutr 134 996S-1002S.

15. Campbell B, Kreider RB, Ziegenfuss T, La Bounty P, Roberts M, et al. (2007) International Society of Sports Nutrition position stand: protein and exercise. J Int Soc Sports Nutr 4: 8.

16. Kreider RB, Wilborn CD, Taylor L, Campbell B, Almada AL, et al. (2010) ISSN exercise \& sport nutrition review: research \& recommendations. J Int Soc Sports Nutr 7: 7

17. Tang JE, Manolakos JJ, Kujbida GW, Lysecki PJ, Moore DR, et al. (2007) Minimal whey protein with carbohydrate stimulates muscle protein synthesis following resistance exercise in trained young men. Appl Physiol Nutr Metab 32. $1132-1138$

18. Kreider RB, Earnest CP, Lundberg J, Rasmussen C, Greenwood M, et al. (2007) Effects of ingesting protein with various forms of carbohydrate following resistance-exercise on substrate availability and markers of anabolism, catabolism, and immunity. J Int Soc Sports Nutr 4: 18.

19. Willoughby DS, Stout JR, Wilborn CD (2007) Effects of resistance training and protein plus amino acid supplementation on muscle anabolism, mass, and strength. Amino Acids 32: 467-477.

20. Kerksick CM, Rasmussen CJ, Lancaster SL, Magu B, Smith P, et al. (2006) The effects of protein and amino acid supplementation on performance and training adaptations during ten weeks of resistance training. J Strength Cond Res 20: 643-653.

21. Cribb PJ, Williams AD, Hayes A (2007) A creatine-protein-carbohydrate supplement enhances responses to resistance training. Med Sci Sports Exerc 39: $1960-1968$

22. McGregor RA, Poppitt SD (2013) Milk protein for improved metabolic health: review of the evidence. Nutr Metab (Lond) 10: 46.

23. Hulmi JJ, Kovanen V, Selänne H, Kraemer WJ, Häkkinen K, et al. (2009) Acute and long-term effects of resistance exercise with or without protein ingestion on muscle hypertrophy and gene expression. Amino Acids 37: 297-308.

24. Reitelseder S, Agergaard J, Doessing S, Helmark IC, Lund P, et al. (2011) Whey and casein labeled with L-[1-13C]leucine and muscle protein synthesis: effect of resistance exercise and protein ingestion. Am J Physiol Endocrinol Metab 300: E231-242.

25. West DW, Burd NA, Coffey VG, Baker SK, Burke LM, et al. (2011) Rapid aminoacidemia enhances myofibrillar protein synthesis and anabolic intramuscular signaling responses after resistance exercise. Am J Clin Nut 94: 795-803.

26. Cribb PJ, Hayes A (2006) Effects of supplement timing and resistance exercise on skeletal muscle hypertrophy. Med Sci Sports Exerc 38: 1918-1925.

27. Snyder BS, Haub MD (2007) Whey, Casein, and Soy Proteins. Chapter 8, in Sports Nutrition Fats and Proteins, JA Driskell (Edr.), CRC Press 143-163.

28. Marshall K (2004) Therapeutic applications of whey protein. Altern Med Rev 9: 136-156. 
29. Wong CW, Watson DL (1995) Immunomodulatory effects of dietary whey proteins in mice. J Dairy Res 62: 359-368.

30. Cockburn E, Stevenson E, Hayes PR, Robson-Ansley P, Howatson G (2010) Effect of milk-based carbohydrate-protein supplement timing on the attenuation of exercise-induced muscle damage. Appl Physiol Nutr Metab 35: 270-277.

31. Hoffman JR, Falvo MJ (2004) Protein- Which is the best? J Sports Sci Med 13: $118-130$.

32. Bucci LR, Unlu L (2000) Protein and amino acid supplements in exercise and sport., in Energy yielding macronutrients and energy metabolism in sports nutrition, I Wolinsky, Driskell JA, (Edr.), CRC Press: Boca Raton, FL. 191-212.

33. Manninen $\mathrm{AH}$ (2004) Protein hydrolysates in sports and exercise: a brief review. J Sports Sci Med 3: 60-63.

34. Calbet JA, MacLean DA (2002) Plasma glucagon and insulin responses depend on the rate of appearance of amino acids after ingestion of differen protein solutions in humans. J Nutr 132: 2174-2182.

35. Holmer-Jensen J, Mortensen LS, Astrup A, de Vrese M, Holst JJ, et al. (2013) Acute differential effects of dietary protein quality on postprandial lipemia in obese non-diabetic subjects. Nutr Res 33: 34-40

36. Bounous G, Gervais F, Amer V, Batist G, Gold P (1989) The influence of dietary whey protein on tissue glutathione and the diseases of aging. Clin Invest Med 12: 343-349.

37. Dangin M, Boirie Y, Garcia-Rodenas C, Gachon P, Fauquant J, et al. (2001) The digestion rate of protein is an independent regulating factor of postprandial protein retention. Am J Physiol Endocrinol Metab 280: E340-348.

38. Tipton KD, Elliott TA, Cree MG, Wolf SE, Sanford AP, et al. (2004) Ingestion of casein and whey proteins result in muscle anabolism after resistance exercise. Med Sci Sports Exerc 36: 2073-2081.

39. Paul GL (2009) The rationale for consuming protein blends in sports nutrition. $J$ Am Coll Nutr 28 Suppl: 464S-472S

40. Tipton KD (2011) Efficacy and consequences of very-high-protein diets for athletes and exercisers. Proc Nutr Soc 70: 205-214.

41. Yang Y, Churchward-Venne TA, Burd NA, Breen L, Tarnopolsky MA, et al (2012) Myofibrillar protein synthesis following ingestion of soy protein isolate at rest and after resistance exercise in elderly men. Nutr Metab (Lond) 9: 57.

42. FAO United Nations Expert Consultation (Ed), (2011) Dietary protein quality evaluation in human nutrition: Auckland, New Zealand

43. Dangin M, Guillet C, Garcia-Rodenas C, Gachon P, Bouteloup-Demange C et al. (2003) The rate of protein digestion affects protein gain differently during aging in humans. J Physiol 549: 635-644.

44. Hildebrandt W, Hamann A, Krakowski-Roosen H, Kinscherf R, Dugi K, et al. (2004) Effect of thiol antioxidant on body fat and insulin reactivity. J Mol Med (Berl) 82: 336-344.

45. Cribb PJ, Williams AD, Carey MF, Hayes A (2006) The effect of whey isolate and resistance training on strength, body composition, and plasma glutamine. Int J Sport Nutr Exerc Metab 16: 494-509.

46. Breen L, Phillips SM (2011) Skeletal muscle protein metabolism in the elderly: Interventions to counteract the 'anabolic resistance' of ageing. Nutr Metab (Lond) 8: 68

47. Hall WL, Millward DJ, Long SJ, Morgan LM (2003) Casein and whey exer different effects on plasma amino acid profiles, gastrointestinal hormone secretion and appetite. $\mathrm{Br} \mathrm{J}$ Nutr 89: 239-248.

48. Calder PC, Yaqoob P (2004) Amino acids and immune function Chapter 19 in Metabolic and Therapeutic Aspects of Amino Acids in Clinlcal Nutrition, LA Cynober, (Edr.), CRC Press LLC 305-320.

49. Di Pasquale MG (2008) Examples of Useful Nutritional Supplement Formulations Chapter 13, in Amino Acids and Proteins for the Athlete: The Anabolic Edge, MG Di Pasquale, (Edr.), CRC Press 397-426.

50. Lemon PWR (2011) Protein and Amino Acid, chapter 5, in Sport and Exercise Nutrition, SA Lanham-New, Stear, SJ, Shirreffs, SM Collins, AL, (Eds.), WileyBlackwell, USA 41-50.

51. Battermann W (1986) Whey protein for athletes Deutsche Milchwirtschaft, 37 1010-1012.

52. Tipton KD, Elliott TA, Cree MG, Aarsland AA, Sanford AP, et al. (2007) Stimulation of net muscle protein synthesis by whey protein ingestion before and after exercise. Am J Physiol Endocrinol Metab 292: E71-76.
53. Kraemer WJ, Solomon-Hill G, Volk BM, Kupchak BR, Looney DP, et al. (2013) The effects of soy and whey protein supplementation on acute hormonal reponses to resistance exercise in men. J Am Coll Nutr 32: 66-74.

54. Norton L, Wilson GJ (2009) Optimal protein intake to maximize muscle protein synthesis. AgroFood industry hi-tech, 20: 54-57.

55. Burke LM, Hawley JA, Wong SH, Jeukendrup AE (2011) Carbohydrates for training and competition. J Sports Sci 29 Suppl 1: S17-27.

56. Costa R JS, Walters R, Bilzon J LJ, Walsh NP (2011) Effects of immediate postexercise carbohydrate ingestion with and without protein on neutrophil degranulation. Int J Sport Nutr Exerc Metab 21: 205-213.

57. Kerksick CM, Leutholtz B (2005) Nutrient administration and resistance training $\mathrm{J}$ Int Soc Sports Nutr 2: 50-67.

58. Kerksick C, Harvey T, Stout J, Campbell B, Wilborn C, et al. (2008) Internationa Society of Sports Nutrition position stand: nutrient timing. J Int Soc Sports Nutr 5: 17.

59. Cooper R, Naclerio F, Larumbe-Zabala E, Chassin C, Allgrove A, et al (2013) Effects of a Carbohydrate-Protein-Creatine Supplement on Strength Performance and Body Composition in Recreationally Resistance Trained Young Men. JOEP online, 16: 72-85.

60. Biolo G, Maggi SP, Williams BD, Tipton KD, Wolfe RR (1995) Increased rates of muscle protein turnover and amino acid transport after resistance exercise in humans. Am J Physiol 268: E514-E520.

61. Bohé J, Low JF, Wolfe RR, Rennie MJ (2001) Latency and duration of stimulation of human muscle protein synthesis during continuous infusion of amino acids. J Physiol 532: 575-579.

62. Moore DR, Tang JE, Burd NA, Rerecich T, Tarnopolsky MA, et al. (2009) Differential stimulation of myofibrillar and sarcoplasmic protein synthesis with protein ingestion at rest and after resistance exercise. J Physiol 587: 897-904.

63. Burke LM, Hawley JA, Ross ML, Moore DR, Phillips SM, et al. (2012) Preexercise aminoacidemia and muscle protein synthesis after resistance exercise. Med Sci Sports Exerc 44: 1968-1977.

64. Kim PL, Staron RS, Phillips SM (2005) Fasted-state skeletal muscle protein synthesis after resistance exercise is altered with training. J Physiol 568: 283 290

65. Phillips SM, Tipton KD, Aarsland A, Wolf SE, Wolfe RR (1997) Mixed muscle protein synthesis and breakdown after resistance exercise in humans. Am J Physiol 273: E99-107.

66. Areta J, Burke LM, Ross ML, Camera DM, West DD, et al. (2013) Timing and distribution of protein ingestion during prolonged recovery from resistance exercise alters myofibrillar protein synthesis. J Physiol 591: 2319-2331.

67. La Bounty PM, Campbell BI, Wilson J, Galvan E, Berardi J, et al. (2011) International Society of Sports Nutrition position stand: meal frequency. J Int Soc Sports Nutr 8: 4

68. Ziegenfuss TN, Landis J, Lemieux RA (2010) Protein for Sports-New Data and New Recommendations. Strength Cond J 32: 65-70.

69. Cooper R, Naclerio F, Allgrove J, Jimenez A (2012) Creatine supplementation with specific view to exercise/sports performance: an update. J Int Soc Sports Nutr 9: 33 